\title{
Methods for Process Evaluation of Work Environment Interventions
}

\author{
Fredslund, Hanne; Strandgaard Pedersen, Jesper
}

Document Version

Final published version

Publication date:

2004

License

CC BY-NC-ND

Citation for published version (APA):

Fredslund, H., \& Strandgaard Pedersen, J. (2004). Methods for Process Evaluation of Work Environment Interventions.

Link to publication in CBS Research Portal

\footnotetext{
General rights

Copyright and moral rights for the publications made accessible in the public portal are retained by the authors and/or other copyright owners and it is a condition of accessing publications that users recognise and abide by the legal requirements associated with these rights.

Take down policy

If you believe that this document breaches copyright please contact us (research.lib@cbs.dk) providing details, and we will remove access to the work immediately and investigate your claim.
}

Download date: 26. Apr. 2023 


\section{Working Paper}

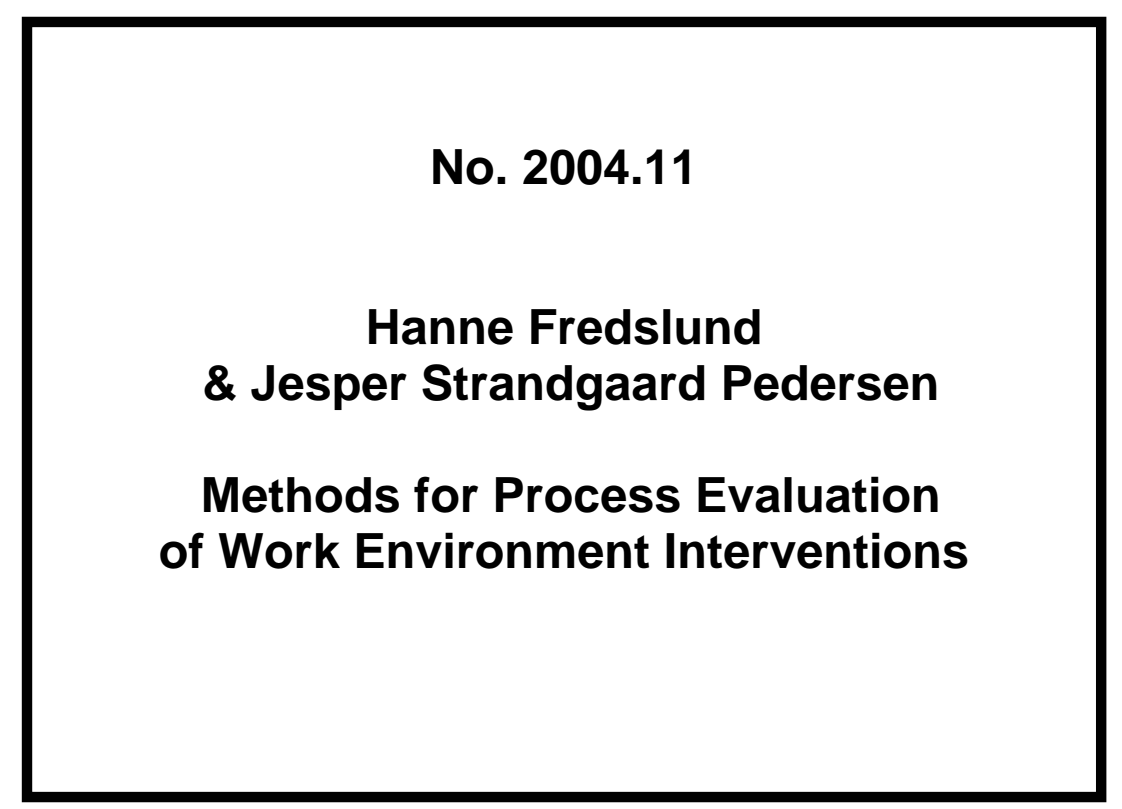

INSTITUT FOR ORGANISATION OG ARBEJDSSOCIOLOGI

Handelshøjskolen i København

Solbjerg Plads 3

2000 Frederiksberg

TIf: $38152815 \quad$ Fax: 38152828 


\title{
Methods for Process Evaluation of Work Environment Interventions
}

\author{
HANNE FREDSLUND \\ National Institute of Occupational Health, Denmark,
}

\section{JESPER STRANDGAARD}

Department of Organization and Industrial Sociology, Copenhagen Business School

\begin{abstract}
Introduction
In recent years, intervention studies have become increasingly popular within occupational health psychology. The vast majority of such studies have focused on interventions themselves and their effects on the working environment and employee health and well-being. Few studies have focused on how the context and processes surrounding the intervention may have influenced the outcomes (Hurrell and Murphy, 1996). Thus, there is still relatively little published research that provides us with information on how to evaluate such strategies and processes (Saksvik, Nytrø, Dahl-Jørgensen, and Mikkelsen, 2002).
\end{abstract}

This paper describes how organisation theory can be used to develop a method for identifying and analysing processes in relation to the implementation of work environment interventions. The reason for using organisation theory is twofold: 1) interventions are never implemented in a vacuum but in a specific organisational context (workplace) with certain characteristics, that the organisation theory can capture, 2) within the organisational sociological field there is a long tradition for studying organisational changes such as workplace interventions.

In this paper process is defined as "individual, collective or management perceptions and actions in implementing any intervention and their influence on the overall result of the intervention” (Nytrø, Saksvik, Mikkelsen, Bohle, and Quinlan, 2000). Process evaluation can be used to a) provide feedback for improving interventions, b) interpret the outcomes of effect evaluation and c) replicate interventions in other settings minimising the number of pitfalls associated with a given intervention (Goldenhar et al., 2001).

\section{Theoretical positions}

The method builds upon four different organisational perspectives: A rational, a natural, a political and an institutional. A perspective is a way to categorise and analyse different ways of understanding organisations, interventions and implementation strategies.

The rational perspective

From a rational perspective, organisations are collectives oriented to the pursuit of relatively specific goals and exhibiting relatively highly formalized social structures (Scott 1992). Within the rational perspective a work environment intervention is based on the following assumptions:

- Interventions are designed and implemented in well-defined phases

- Interventions often aim at increasing the effectiveness of the organisation whilst at the same time solving the identified work environment problem

- The content of the intervention is selected from an analysis of the effectiveness of the different solutions

- $\quad$ Preferably evidence-based interventions are selected

- The component parts of the organisation are oriented to pursuit the goals of an intervention

- The highly formalized social structures ensure that roles and responsibilities in the intervention are given - or at least easy to identify

- Interventions can be designed and managed by the top management (top-down strategy)

- If an intervention is not implemented as expected, there is something wrong with either the theory behind the intervention (theory failure), with the design of the intervention (programme failure), or with the part of the system the intervention is implemented in. 
The rational approach to organisational studies has been criticised for only dealing with the tip of the organisational iceberg. Underneath the visible formalised social structures there are aspects, which are just as (or even more) determining for the implementation processes.

\section{The natural perspective}

According to the natural perspective organisations are collectives whose participants share a common interest in the survival of the system and who engage in collective activities, informally structured, to secure this end (Scott 1992). Interventions that are based on a natural perspective will focus on the values of the different players and on human development. An evaluation of interventions within the natural perspective builds on assumptions such as:

- Interventions are based on the values of the organisation, the project managers, or the employees

- Different players may have different understandings of an intervention

- The aim of the intervention is to develop the employees

- Interventions are better implemented by involving the employees (bottom-up strategy)

- If the official aim of an intervention is not fulfilled this does not necessarily imply failure. The implementation process may have created important organisational learning on the way that can be useful in later interventions or in the daily work.

Thus the natural perspective represents an alternative to the rational approach. Underneath the tip of the iceberg we find different values that affects the implementation of an intervention.

\section{The political perspective}

From a political perspective organisations are open, social systems with potential conflicts and with players in different positions (Borum 1995). In a political perspective, interventions are seen as determined by different conflicting interests inside as well as outside the organisation. Thus organisations are considered to be open systems (Scott 1992). If we evaluate interventions from a political point of view our assumptions about interventions are as follows:

- Interventions are planned, adopted, and implemented because someone has an interest in it

- An intervention can be designed to stabilise or displace existing power relations

- $\quad$ The change agents will typically be powerful individuals or groups. If they don't have the power to get through with the intervention they will make coalitions with other powerful groups

- If the implementation does not succeed it will often be due to a collision of conflicting interest or due to the lack of support from powerful groups.

Also the political perspective offers an alternative to the rational approach where we underneath the tip of the iceberg find different interests and power structures that influence the interventions and implementation processes.

\section{The institutional perspective}

The fourth perspective on organisations is the institutional perspective. Here organisations are understood as open and loosely coupled systems, which manifest themselves through organisation processes (Borum 1995). Interventions in such a system are very difficult to evaluate because it is assumed that:

- Both the intervention and the strategy for implementation take continuous shape and will be adapted in order to address the problems that may come into existence during the processes. This means that we can not design a successful intervention in well-defined phases beforehand

- One can not distinguish between which processes (and effects) that relates to the planned intervention and which relates to other parallel (planned as well as not planned) changes in the organisation

- $\quad$ Planned interventions often bring about unexpected events

- Interventions cannot be isolated to internal affairs because organisations are seen as open systems

- Interventions are implemented in a loosely coupled system where part of the interventions tends to be decoupled.

Under the tip of the organisational iceberg we find loose couplings and organising processes and not an organisation that works like an organisation chart.

It must be emphasised that organisations, interventions and change strategies always represent mixed forms of the perspectives. However, the four perspectives enable us to construct some analytical categories that can structure both the collection and the interpretation of our empirical material. 


\section{The rational perspective}

\section{Methodological implications}

If we take the rational perspective for granted a process evaluation of an intervention must focus on the formal structures and processes, e.g. a) the way the intervention was planned, b) the way the intervention was organised, c) the implementation strategy, and d) the degree of fulfilment of the planned purposes.

The methods we suggest to collect empirical material about the above subjects are written documents about the intervention, questionnaires, and structured interviews with key persons. Since an intervention within a rational system is relatively transparent it is not necessary to use methods that go further below the surface. To analyse the empirical material theories from the rational perspective can be used, such as Mintzberg (1993) or Galbraith (1973).

\section{The natural perspective}

Within a natural perspective, process evaluation focuses on informal structures and processes such as adaptation processes, communication and participation processes, and learning processes. Overall subjects for such a process evaluation could be: a) The agreement between the intervention and the values within the organisation, b) the agreement between the implementation strategy and the values within the organisation, c) the involvement of the different players in planning and implementing the intervention, and d) the planned and the unintended learning (organisational as well as individual) in relation to the intervention and the implementation.

To gain knowledge about these issues it is necessary to employ in-depth qualitative methods such as semi-structured interviews, focus groups, and/or observations. To interpret the empirical material theories such as Schein (1985) or Argyris \& Schön (1996) are suggested, since they are in line with the natural perspective by focusing on respectively values and learning processes.

\section{The political perspective}

From a political perspective a process evaluation must focus on power processes of an intervention such as negotiation and decision processes, influence and authority processes, and institutional framework for behaviour. Overall themes for a process evaluation could be: a) Who decided the content of the intervention and the implementation strategy, b) who were the interested parties in the intervention and what were their interests? c) are there any discourses in play that set limits for the content of the intervention or the implementation strategy.

It is often difficult to get information on power issues. First, because power is often invisible, tacit and almost impossible to document. Second, because power usually is a sensitive issue in organisations. Therefore it is a useful method to find indirect ways of asking about power in qualitative interviews. Furthermore it can be a good idea to create some more informal situations to talk with the different players about power aspects. Finally observations and written sources can be used to analyse power relations. To interpret the empirical material different theories about power can be used, such as Robert A. Dahl (1961) (direct power), Peter Bachrach \& Morton Baratz (1970) (indirect power), Steven Lukes (1974) (power to control consciousness) and Max Weber (1971), Geert Hofstede (1980) or Michel Foucault (1993) (institutional power).

\section{The institutional perspective}

If we accept the chaotic circumstances the institutional perspective builds upon, the purpose of a process evaluation is to identify processes of organising, processes of decoupling and, processes of legitimising. Some of the evaluation subjects could be: a) How was the intervention organised and implemented in practice, b) what other kind of change processes took place before and during the implementation of the intervention, c) has any parts of the intervention been decoupled and, d) is the intervention used to supply the organisation with legitimacy?

As methods to collect empirical material on such subjects we suggest a combination of written sources, interviews, and observations. In the written sources we get information about the formal aim of the intervention. Through interviews and observations we get to know more about the informal processes and changes of practice in the organisation. In the interviews it is recommended to ask questions starting with "what" and "how" instead of "why", because we want information on practice and not on normative reflections. By combining these two methodological approaches, that covers respectively formal and informal aspects of the intervention, it becomes possible to uncover decoupled elements. To analyse the empirical material we suggest theory from the institutional school such as Powell \& DiMaggio (1991) or Weick (1979). 


\section{An empirical example}

The methods for process evaluation presented in this paper have been used in a large research project investigating the effects of workplace interventions in a number of female-dominated workplaces in Denmark. Whenever a process evaluation is carried out it is necessary to decide what perspective to apply to the evaluation, which subjects to include, which methods to use for collecting empirical material, and which theories to choose for interpreting the material. All these choices are determined by the purpose of the process evaluation and by the knowledge we have of the specific intervention and the context it is implemented in. This means, that we did not use the same methods for evaluation the different interventions. In interventions where the project managers seemed to have a natural approach it was obvious to include subjects from the natural perspective as suggested in this paper. In interventions where conflicting interest seemed to block the way for the implementation of an intervention the political perspective was used. And in interventions where other organisational changes seemed to overshadow the intervention the institutional perspective was brought into play. But in none of the many process evaluations did we use only one single perspective. We always used a mix of the four perspectives adjusted to the specific intervention and the specific context. An example:

In the process evaluation described in Nielsen \& Fredslund (2004) we used subjects from all four perspectives. Since the purpose of the process evaluation was to get as far below the tip of the organisational iceberg as possible we used observations, individual interviews, focus groups and written documents to study the processes. In the interview guides we included the subjects from the four perspectives that could deepen the knowledge we got from participating in the processes and that could give us knowledge about the topics we wanted to include in the reports for the two work places. The subjects were: 1) Evaluation of the activities in the intervention (rational perspective), 2) evaluation of the project organisation and the involvement of the employees (natural perspective), 3) identification of the 'ownership' of the intervention (political perspective) and 4) the influence other organisational changes and processes had on the interventions (institutional perspective).

We did not do theoretical interpretations of each of the many process evaluations we did in the research project. Instead we have done an overall interpretation of all the process evaluations. The interpretation are structured by the four perspectives in order to find some general tendencies in the processes in relation to the implementations at the different workplaces. In some cases it seems that the project managers applied a perspective that to some extent did not match the type of organisation or group of employees the intervention was directed to.

\section{Conclusion}

In this paper we have described how organisation theory was used to develop a method for process evaluation. It has been the ambition to draw a line between the organisational perspective, assumptions about interventions, subjects for process evaluation, methods to collect empirical material, and finally theory to interpret the collected material.

By using organisation theory we ensure that the themes for a process evaluation are not chosen at random but consider the characteristics of a) the intervention, and b) the context in which the intervention is implemented. Furthermore, the four perspectives make it obvious, that the outcome of a process evaluation is very much dependent on the perspective, we choose. Thus, we will claim that the development of a simple standard method for process evaluation will result in evaluations that do not reflect the complexity and the differences in the contexts that are so crucial for interpreting the processes in relation to the implementation of interventions. By operating with several perspectives it becomes possible to adjust the evaluation subjects, the methods and the theories to the specific intervention and context. And that is the reason for suggesting a flexible method for process evaluation. 


\section{Reference List}

ARGYRIS, C. \& SCHÖN D.A. (1996). Organizational Learning II. Theory, Method, and Practice. Reading: AddisonWesley Publishing Company, Inc, 1996

ARGYRIS, C. \& SCHÖN D.A. (1996). Organizational Learning II. Theory, Method, and Practice. Reading: AddisonWesley Publishing Company, Inc, 1996

BACHRACH, P. \& BARATZ M. (1970). Power and Poverty New York: Oxford University Press.

BORUM, F. (1995). Strategier for organisationsœendring. København: Handelshøjskolens Forlag.

DAHL, R.A. (1961). Who Governs? New Haven: Yale University Press.

FOUCAULT, M. (1993) Diskursens ordning, Stockholm: Brutus Östlings Bokförlag

GALBRAITH, J.K. (1973). Designing Complex Organizations. Reading, Mass.: Addison-Wesley.

GOLDENHAR, L., LAMONTAGNE, A., KATZ, T., HEANEY, C., \& LANDSBERGIS, P. (2001). The intervention research process in occupational safety and health: An overview from the National Occupational Research Agenda Intervnetion Effectiveness Research Team. Journal of Occupational and Environmental Medicine, 43, 616-622.

HOFSTEDTE, G. (1980). Cultures' Consequences. International Differences in Work-Related Values. London: Sage Publications.

HURRELL, J. \& MURPHY, L. (1996). Occupational stress intervention. American Journal of Industrial Medicine, 29, 338-341.

LUKES, S. (1974) Power. A Radical View. London: MacMillan.

MINTZBERG, H. (1993). Structure in Fives. Designing Effective Organizations. Englewood Cliffs: Prentice Hall, Inc.

NIELSEN, K. \& FREDSLUND H. (2004) Using Process Evaluation to Understand the Impact of Interventions. Proceedings from the $6^{\text {th }}$ EA-OHP Conference. Portugal: Oporto.

NYTRØ, K., SAKSVIK, P. Ø., MIKKELSEN, A., BOHLE, P., \& QUINLAN, M. (2000). An appraisal of key factors in the implementation of occupational stress interventions. Work \& Stress, 14, 213-225.

POWELL, W. \& DiMAGGIO P.J. (eds.) (1991). The New Institutionalism Analysis. Chicago: The University of Chicago Press.

SAKSVIK, P. Ø., NYTRØ, K., DAHL-JØRGENSEN, C., \& MIKKELSEN, A. (2002). A process evaluation of individual and organizational occupational stress and health interventions. Work \& Stress, 16, 37-57.

SCHEIN, E.H. (1985). Organizational Culture and Leadership. San Francisco: Jossey-Bass.

SCOTT, W. R. (1992). Organizations. Rational, Natural, and Open Systems. Englewood Cliffs: Prentice-Hall, Inc.

WEBER, M. (1971). Makt og Buråkrati. Oslo: Gyldendal.

WEICK, K. (1979). The Social Psychology of Organizing. Reading, Mass.: Addison-Wesley. 